May $2002 \quad$ N NREL/CP-520-32187

\title{
Polycrystalline Thin Film Photovoltaics: Research, Development, and Technologies
}

\section{Preprint}

H.S. Ullal, K. Zweibel, and B. von Roedern

To be presented at the $29^{\text {th }}$ IEEE PV Specialists Conference

New Orleans, Louisiana

May 20-24, 2002

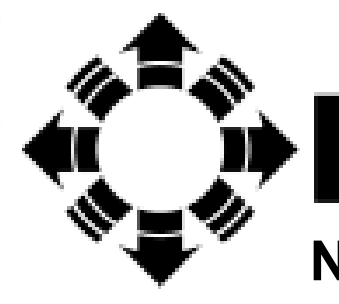

National Renewable Energy Laboratory

1617 Cole Boulevard

Golden, Colorado 80401-3393

NREL is a U.S. Department of Energy Laboratory

Operated by Midwest Research Institute $\bullet$ Battelle $\bullet$ Bechtel

Contract No. DE-AC36-99-G010337 


\section{NOTICE}

The submitted manuscript has been offered by an employee of the Midwest Research Institute (MRI), a contractor of the US Government under Contract No. DE-AC36-99G010337. Accordingly, the US Government and MRI retain a nonexclusive royalty-free license to publish or reproduce the published form of this contribution, or allow others to do so, for US Government purposes.

This report was prepared as an account of work sponsored by an agency of the United States government. Neither the United States government nor any agency thereof, nor any of their employees, makes any warranty, express or implied, or assumes any legal liability or responsibility for the accuracy, completeness, or usefulness of any information, apparatus, product, or process disclosed, or represents that its use would not infringe privately owned rights. Reference herein to any specific commercial product, process, or service by trade name, trademark, manufacturer, or otherwise does not necessarily constitute or imply its endorsement, recommendation, or favoring by the United States government or any agency thereof. The views and opinions of authors expressed herein do not necessarily state or reflect those of the United States government or any agency thereof.

Available electronically at http://www.osti.gov/bridge

Available for a processing fee to U.S. Department of Energy and its contractors, in paper, from:

U.S. Department of Energy

Office of Scientific and Technical Information

P.O. Box 62

Oak Ridge, TN 37831-0062

phone: 865.576 .8401

fax: 865.576.5728

email: reports@adonis.osti.gov

Available for sale to the public, in paper, from:

U.S. Department of Commerce

National Technical Information Service

5285 Port Royal Road

Springfield, VA 22161

phone: 800.553 .6847

fax: 703.605.6900

email: orders@ntis.fedworld.gov

online ordering: http://www.ntis.gov/ordering.htm

Printed on paper containing at least $50 \%$ wastepaper, including $20 \%$ postconsumer waste 


\title{
POLYCRYSTALLINE THIN FILM PHOTOVOLTAICS: RESEARCH, DEVELOPMENT, AND TECHNOLOGIES
}

\author{
Harin S. Ullal, Kenneth Zweibel, and Bolko von Roedern \\ National Center for Photovoltaics (NCPV) \\ National Renewable Energy Laboratory (NREL) \\ 1617 Cole Boulevard \\ Golden, CO 80401 USA \\ Tel: (303) 384 6486; Fax: (303) 384 6430; E-mail: harin_ullal@nrel.gov
}

\begin{abstract}
II-VI binary thin-film solar cells based on cadmium telluride (CdTe) and I-III-VI ternary thin-film solar cells based on copper indium diselenide (CIS) and related materials have been the subject of intense research and development in the past few years. Substantial progress has been made thus far in the area of materials research, device fabrication, and technology develop-ment, and numerous applications based on CdTe and CIS have been deployed worldwide. World record efficiency of $16.5 \%$ has been achieved by NREL scientists for a thinfilm CdTe solar cell using a modified device structure. Also, NREL scientists achieved world-record efficiency of $21.1 \%$ for a thin-film CIGS solar cell under a $14 \mathrm{X}$ concentration and AM1.5 global spectrum. When measured under a AM1.5 direct spectrum, the efficiency increases to $21.5 \%$. Pathways for achieving $25 \%$ efficiency for tandem polycrystalline thin-film solar cells are elucidated. R\&D issues relating to $\mathrm{CdTe}$ and $\mathrm{CIS}$ are reported in this paper, such as contact stability and accelerated life testing in CdTe, and effects of mositure ingress in thin-film CIS devices. Substantial technology development is currently under way, with various groups reporting power module efficiencies in the range of $7.0 \%$ to $12.1 \%$ and power output of 40.0 to $92.5 \mathrm{~W}$. A number of lessons learned during the scale-up activities of the technology development for fabrication of thin-film power modules are discussed. The major global players actively involved in the technology development and commercialization efforts using both rigid and flexible power modules are highlighted.
\end{abstract}

\section{INTRODUCTION}

Polycrystalline thin-film compounds based on II-VI binary thin-film CdTe solar cells and I-III-VI ternary thin-film CIS-based solar cells have made remakable progress in the past few years. World record total-area efficiency of $16.5 \%$ has been achieved by NREL scientists for a thinfilm CdTe solar cell using a modified device structure of CTO/ZTO/CdS/CdTe/contact. The several advantages of this novel structure as compared to the conventional structure of $\mathrm{TO} / \mathrm{CdS} / \mathrm{CdTe} /$ contact are highlighted below. A new $\mathrm{O}_{2}$-alloyed $\mathrm{CdS}$ layer whose bandgap varies with the $\mathrm{O}_{2}$ content has been developed at NREL labs. Contact stability and accelerated life testing (ALT) of these devices is the focus of research at several laboratories.
NREL scientists also achieved world-record, total-area efficiency of $21.5 \%$ for a thin-film CIGS under $14 \mathrm{X}$ concentration and AM1.5 global spectrum. When measured under $\mathrm{AM} 1.5 \%$ direct spectrum, the total-area efficiency increases to $21.5 \%$. Details of the cell processing are given below. The Institute of Energy Conversion (IEC) at the University of Delaware has set a world-record, totalarea efficiency of $16.9 \%$ for a thin-film copper indium aluminum diselenide (CIAS) solar cell, verified by NCPV/NREL. Also, n- and p-type transparent conductors (TCs) used in thin-film solar cell fabrication are described below. n-type TCs used in thin-film solar cell applications are ITO, CTO, TO, ZnO, and ZTO; p-type TCs that are in the early stages of development are $\mathrm{CAO}, \mathrm{CIO}, \mathrm{CSO}$, and $\mathrm{ZnO}$. When fully developed, p-type TCs will have some unique advantages in solar cell fabrication, especially in a tandem device. It has been established that the efficiency of single-junction polycrystalline thin film solar cells has a practical limit of about $20 \%$ under 1 -sun illumination. In order to move the technology forward in the next 5 to 10 years, tandem junction thin-film solar cells are the logical choice to advance the state-of-art efficiency to about $25 \%$. Pathways for achieving this long-term goal are elucidated. $\mathrm{R} \& \mathrm{D}$ issues relating to $\mathrm{CdTe}$ and CIS materials and devices are also presented.

A number of organizations worldwide are involved in the technology development of thin-film CdTe and CIS modules. Power modules in the efficiency range of $7.0 \%$ to $12.1 \%$ and power output of 40.0 to $92.5 \mathrm{~W}$ have been fabricated by several groups worldwide. Numerous lessons learned in the design, development, processing, and encapsulations/packaging of thin-film module fabrication is also discussed in detail.A number of applications based on CdTe \& CIS have been deployed worldwide with gridconnected system sizes varying from 10.0 to $250 \mathrm{~kW}$.

\section{TRANSPARENT CONDUCTORS}

An important component for making high-efficiency thin-film solar cells are n-type current-carrying TCs. The basic properties for making high-quality TCs are: high conductivity, high optical transmission, low surface roughness, thermal stability, chemical stability, work function, crystallinity, hardness, and cost. This is depicted in Table 1. Typical n-type TCs used in solar cell fabrication are ITO, TO, CTO, ZnO, and ZTO. The typical values for 
bandgaps are in the range of 3.3 to $3.8 \mathrm{eV}$; carrier concentration is in the range of $10^{20}$ to $10^{21} \mathrm{cc}^{-1}$; conductivity of $10^{4}(\mathrm{ohm}-\mathrm{cm})^{-1}$; sheet resistance about 5 to $10 \mathrm{ohms}$ per sq.; and optical transmission greater than $85 \%$ over the visible part of the solar spectrum. ZTO is mainly used as a buffer layer in cell fabrication. ITO, $\mathrm{SnO}_{2}$, and $\mathrm{ZnO}$ are currently used for module fabrication. ITO is fabricated by sputtering, $\mathrm{SnO}_{2}$ by $\mathrm{CVD}$ and spray deposition, and $\mathrm{ZnO}$ by MOCVD and sputtering. CTO is deposited by sputtering and is currently being used for fabricating world-record laboratory cells. CTO has superior electrical and optical properties when compared to conventional $\mathrm{SnO}_{2}[1]$.

\section{Table 1. Transparent Conductors (Requirements)}

$$
\begin{array}{ll}
\text { - High optical transmission } & \begin{array}{l}
\text { Adhesion - Thermal } \\
\text { coefficient match }
\end{array} \\
\text { - Low electrical resistivity } & \text { Crystallinity } \\
\text { - Low surface roughness } & \text { Hardness } \\
\text { - Thermal stability to withstand } & \text { - Cost } \\
\text { processing temperature } & \\
\text { - Chemical stability } &
\end{array}
$$

Recently, p-type TCs have emerged and could potentially have a significant impact in fabricating tandem polycrystalline thin-film devices. The most commonly used p-type TCs are CAO, CIO, CSO, and $\mathrm{ZnO}$. They are mainly, but not exclusively from the crystallographic family of delafossite [2]. The main drawback of p-type TCs is its lower carrier concentration, which is several orders of magnitude lower compared to n-type TCs. The typical value varies from $10^{16}$ to $10^{17} \mathrm{cc}^{-1}$, mobility is in the range of 0.1 to $10 \mathrm{~cm}^{2} \mathrm{~V}^{-1} \mathrm{~s}^{-1}$, and bandgaps are about $3.5 \mathrm{eV}$. Major doping improvements are needed to improve the carrier concentration and also the mobility without a loss in optical transmission. Both n- and p-type TCs are listed in Table 2.

\section{Table 2. Transparent Conductors (Types)}

\begin{tabular}{|ll|}
\hline n-type & p-type \\
$\mathrm{ITO}^{*}$ & $\mathrm{CuAlO}_{2}(\mathrm{CAO})$ \\
$\mathrm{SnO}_{2}: \mathrm{F}, \mathrm{Cl}, \mathrm{Sb}^{*}(\mathrm{TO})$ & $\mathrm{CuInO}_{2}(\mathrm{ClO})$ \\
$\mathrm{ZnO}: \mathrm{Al}, \mathrm{B}, \mathrm{Ga}, \mathrm{In}^{*}$ & $\mathrm{Cu}_{2} \mathrm{SrO}_{2}$ (CSO) \\
$\mathrm{CdO}: \mathrm{F}$ & $\mathrm{ZnO}: \mathrm{N}, \mathrm{Ga}$ \\
$\mathrm{Cd}_{2} \mathrm{SnO}_{4}$ (CTO) & \\
$\mathrm{In}_{2} \mathrm{O}_{3}$ (IO) & \\
$\mathrm{In}_{2} \mathrm{O}_{3}: \mathrm{Mo}$ & \\
$\mathrm{Zn}_{2} \mathrm{SnO}_{4}$ (ZTO) & \\
${ }^{*}$ Commercial Products & \\
\hline
\end{tabular}

\section{II-VI THIN-FILM SOLAR CELLS}

II-VI binary thin-film solar cell based on CdTe is one of the most promising thin-film solar cell. CdTe has an optimum bandgap of $1.45 \mathrm{eV}$, which is an excellent match for the solar spectrum. Also, its high absorption coefficient implies that a few microns of the absorber film are sufficient for cell fabrication. A typical thin-film CdTe solar cell structure is glass/SnO2/CdS/CdTe/ contact and is shown in Fig. 1. Several back contacts investigated worldwide are reported elsewhere [3]. A world record total-area efficiency of $16.5 \%$ has been achieved by NREL scientists using a modified device structure of glass/CTO/ZTO/CdS/CdTe/graphite [4]. There are several advantages of this new structure as compared to the conventional device structure. The CTO has higher optical transmission, lower resistivity, and smoother surface roughness as depicted from AFM investigation.

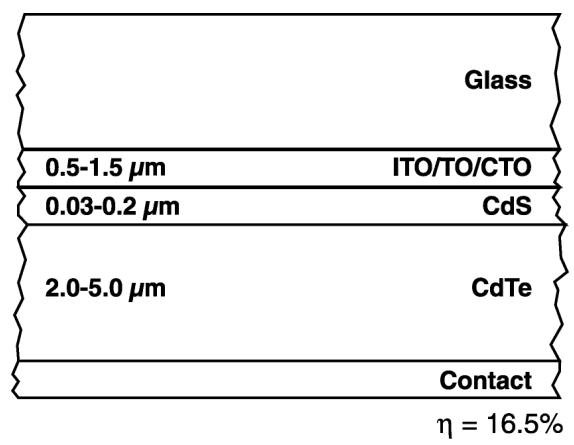

Fig. 1. Thin-film CdTe solar cell structure.

One of the critical processing steps for high-efficiency devices is a $\mathrm{CdCl}_{2}$ heat treatment,which may be either a wet chemical process or a dry vapor process. The current trend is to move toward a dry vapor process because it has better process control, and it eliminates the handling of wet chemicals in the laboratory environment. Fig. 2 is an AFM image of a CdTe film that depicts the significant grain growth after the vapor $\mathrm{CdCl}_{2}$ heat treatment done at about $400^{\circ} \mathrm{C}$ for $15-20$ minutes, which minimizes grain boundary defects for achieving high efficiency devices. Another important effect that is observed is the intermixing that takes place at the $\mathrm{CdS} / \mathrm{CdTe}$ interface. The amount of sulphur in the solid solution varies from $2 \%$ to $12 \%$ depending on the deposition temperature of the absorber layer for cell fabrication [5]. A new $\mathrm{O}_{2}$-alloyed $\mathrm{CdS}$ layer whose bandgap varies from 2.42 to $3.17 \mathrm{eV}$ with the $\mathrm{O}_{2}$ content has been developed by NREL scientists [6].
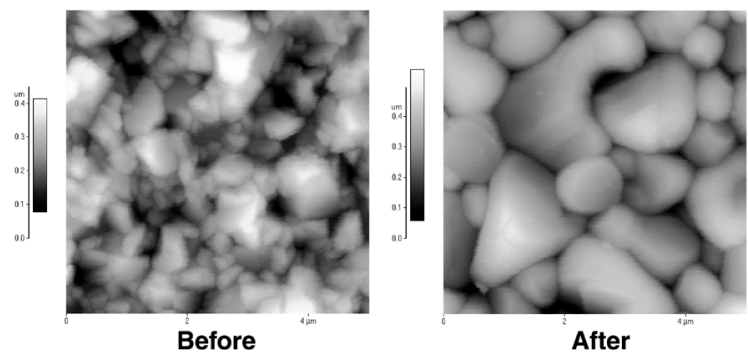

Fig. 2. AFM micrograph of before and after vapor $\mathrm{CdCl}_{2}$ heat treatment.

One of the most important research issues is the stability of thin-film CdTe devices. Table 3 highlights the accelerated life testing (ALT) that is currently under way within the National CdTe R\&D Team to address these issues. The several variables that have been investigated 
are illumination, temperature, ambient condition, bias, time, etching prior to depositing the back contacts, and $\mathrm{CdCl}_{2}$ process details. More specifically, researchers are studying effects of micro-non-uniformity, capacitancevoltage measurements, chlorine issues stated above, back barrier height, defect chemistry, Cu movement in the device, the effect of $\mathrm{O}_{2}$, and the role of $\mathrm{S}$ at the $\mathrm{CdS} / \mathrm{CdTe}$ interface.

Table 3. CdTe - Accelerated Life Testing

\begin{tabular}{|l|l|}
\hline - Illumination: & 0.5 Sun, 1 Sun, 2 Suns, Dark \\
\hline Temperature: & $60,70,80,90,100,110,120^{\circ} \mathrm{C}$ \\
\hline - Ambient: & Air, Ar, $\mathrm{He}, \mathrm{N}_{2}, \mathrm{O}_{2}$ \\
\hline - Bias: & $\mathrm{I}_{\mathrm{sc}}, \mathrm{V}_{\mathrm{oc}}, \mathrm{P}_{\text {max }}, \mathrm{R}_{\mathrm{rev}}, \mathrm{F}_{\text {for }}$ \\
\hline - Time: & 1 to 4000 hours \\
\hline Etching: & $\mathrm{BM}, \mathrm{BDH}, \mathrm{NP}, \mathrm{no}$ etch \\
\hline Measurements: & $\mathrm{I}-\mathrm{V}, \mathrm{Q}-\mathrm{E}, \mathrm{C}-\mathrm{V}, \mathrm{PL}$ \\
\hline Characterizations: & $\mathrm{AES}, \mathrm{AFM}, \mathrm{EDS}, \mathrm{SEM}, \mathrm{SIMS}, \mathrm{XPS}, \mathrm{XRD}$ \\
\hline
\end{tabular}

\section{I-III-VI THIN-FILM SOLAR CELLS}

I-III-VI ternary thin-film solar cell based on CIS and related alloys and materials is another promising thin-film solar for both space and terrestrial applications. CIS is a direct-bandgap material and has a bandgap of about 0.9 $\mathrm{eV}$. When $\mathrm{Ga}$ is introduced into the absorber layer, the bandgap increases to about $1.12 \mathrm{eV}$ with a Ga content of less than $30 \%(\mathrm{Ga} / \mathrm{Ga}+\mathrm{In})$. A typical thin-film CIS based solar cell substrate structure is $\mathrm{ZnO} / \mathrm{CdS} / \mathrm{CIS} / \mathrm{Mo} / g$ lass and is shown in Fig. 3. A world -record total-area efficiency of $21.1 \%$ under $14 \mathrm{X}$ concentration and global AM1.5 spectrum has been achieved by NREL scientists [7]. When measured under AM1.5 direct spectrum, the efficiency increases to $21.5 \%$.

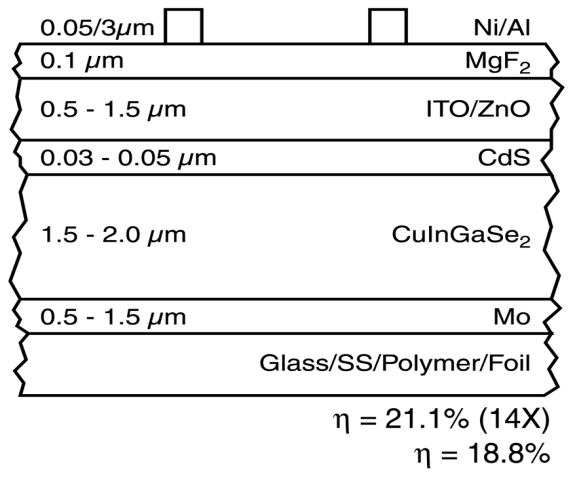

Fig. 3. Thin-film CIS solar cell structure.

Under 1-sun condition, the total-area efficiency of thin-film CIGS solar cell is $18.8 \%$. To enhance the efficiency to $20 \%$ under 1 -sun condition, improvements need to be made to minimize defects in the CIGS absorber film. Fig. 4 is a TEM cross section showing dislocations near the CdS/CIGS interface that need to be eliminated or minimized by optimizing the deposition conditions. Addi- tionally, the Institute of Energy Conversion at the University of Delaware, Newark, Delaware, has set a worldrecord, total-area efficiency of $16.9 \%$ for a thin-film CIAS solar cell, verified by NCPV/NREL. Here the $\mathrm{Ga}$ is replaced by the Al. The bandgap of this device is $1.15 \mathrm{eV}$. The $\mathrm{Al} / \mathrm{Al}+\mathrm{In}$ is less than $30 \%$. The CIAS film is grown by the physical vapor deposition method [8].

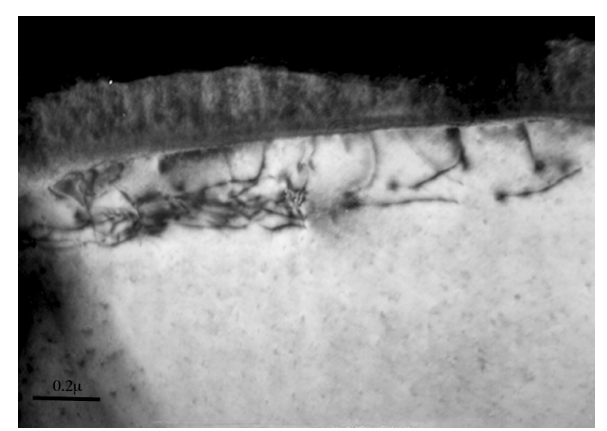

Fig. 4. TEM cross section of thin-film CIGS solar cell showing dislocations.

One of the most active area of research is alternate buffer layers. A comprehensive list of buffer layers investigated by various groups worldwide is reported elsewhere [9]. The performance characteristics and process robustness of these devices using alternate buffer layers is not comparable to CBD CdS. The most compelling research issue related to CIS devices is the role of moisture and its impact on long term reliability. Moisture ingress appears to have a detrimental effect on device performance. Other areas of scientific research is the development of superstrate structure, development of wide-bandgap chalcopyrite absorber films, low-temperature processing of absorber film, in-line process diagonostics, and modeling. Alternate substrates such as stainless steel, polymers, and metal foils are also being investigated for fabricating lightweight, flexible CIGS devices for space applications. CdS/CIGS interface studies done by NREL researchers have shown that $\mathrm{Cd}$ diffuses into the CIGS absorber and may play a significant role in junction formation [10].

\section{TANDEM THIN FILM SOLAR CELLS}

The efficiency of single junction polycrystalline thin film solar cells efficiency has a practical laboratory limit of about $20 \%$ under 1 -sun illumination. To move the technology forward in the next 5 to 10 years, tandem-junction solar cells are the logical choice for advancing the stateof-art efficiency to $25 \%$, based on the scientific knowledge developed for single-junction devices. The theoretical limit for the conversion efficiency of tandem thin-film solar cells with two junctions is about $29 \%$. Modeling work done by Fan of Kopin [11] and Kuwano of Sanyo in the early 1980s indicate that the ideal bandgaps for highperformance cells are $1.7 \mathrm{eV}$ for the top cell and $1.1 \mathrm{eV}$ for the bottom cell. A typical solar cell structure could be ITO/CdS/(CGS, CIAS, CIGSS, CdZnTe, CdSe)/p$\mathrm{ZnO} / \mathrm{ITO} / \mathrm{CdS} / \mathrm{CIGS} / \mathrm{Mo} / g$ lass for a two terminal device; it is shown in Fig. 5. Major challenge in developing this tandem-junction solar cell is the development of a top cell with a bandgap of $1.7 \mathrm{eV}$ using low-temperature absorber 
processing. Other challenge is to develop a transparent, heavily-doped, low- resistance tunnel junction connecting the top and bottom cells. Alternately, the growth of low carrier concentration and high-mobility TCs to minimize free-carrier absorption for tunnel junction formation is needed. The research is in the very early stages of development with much of the focus being on fabricating the top cell with a bandgap of $1.7 \mathrm{eV}$.

\begin{tabular}{|c|c|}
\hline Thickness & Eg \\
\hline $0.5-1.5 \mu \mathrm{m}$ & ITO $3.7 \mathrm{eV}$ \\
\hline $0.03-0.05 \mu \mathrm{m}$ & CdS $2.4 \mathrm{eV}$ \\
\hline $1.0-2.0 \mu \mathrm{m}$ & $\mathrm{CuGaSSe}_{2} / \mathrm{CuGaSe}_{2} / \mathrm{CuInAISe}_{2} / \mathrm{CdZnTe} / \mathrm{CdSe} \sim 1.7 \mathrm{eV}$ \\
\hline $0.01 \mu \mathrm{m}$ & p-CuAlO ${ }_{2}, \mathrm{CuGaO}_{2}, \mathrm{SrCu}_{2} \mathrm{O}_{2} 3.3 \mathrm{eV}$ \\
\hline $0.01 \mu \mathrm{m}$ & ITO $3.7 \mathrm{eV}$ \\
\hline $0.03-0.05 \mu \mathrm{m}$ & CdS $2.4 \mathrm{eV}$ \\
\hline $1.5-2.0 \mu \mathrm{m}$ & CulnGaSe $_{2} 1.1 \mathrm{eV}$ \\
\hline $0.5-1.5 \mu \mathrm{m}$ & Mo \\
\hline & Glass/SS/Polymer \\
\hline
\end{tabular}

Fig. 5. Tandem thin-film solar cell structure.

\section{TECHNOLOGY DEVELOPMENT}

From a technology development standpoint, a number of groups worldwide are actively involved in developing thin-film rigid and flexible power modules for various applications. Three companies are currently in the early stages of CdTe product commercialization; Antec Solar (AS), Germany; BP Solar (BPS), USA; and First Solar (FS), USA. The major players for thin-film CIS-based module development are Energy Photovoltaics, USA; Global Solar Energy, (GSE), USA; Honda Engineering, Japan; Shell Solar Industries (SSI), USA; and Wurth Solar, Germany. Table 4 summarizes the champion thin-film $\mathrm{CdTe}$ and CIS modules fabricated by several industrial group worldwide.

\section{Table 4. Polycrystalline Thin Film} Photovoltaic Modules

\begin{tabular}{|l|l|c|c|c|c|}
\hline \multicolumn{9}{|c|}{ Material } & Area $\left(\mathrm{cm}^{2}\right)$ & Eff (\%) & Power (W) & Date \\
\hline Organization & CdTe & 8390 & $11.0^{*}$ & $92.5^{*}$ & $09 / 01$ \\
BP Solar & CIGS & 6623 & 10.4 & 68.9 & $11 / 01$ \\
Furth Solar & CdTe & 6612 & $10.1^{*}$ & $67.1^{*}$ & $12 / 01$ \\
Matsushita Solar & CdTe & 5413 & 11.0 & 59.0 & $05 / 00$ \\
Global Solar & CIGS & 7714 & $7.4^{\star}$ & $57.3^{\star}$ & $01 / 03$ \\
Antec Solar & CdTe & 6633 & 7.0 & 46.7 & $11 / 01$ \\
Shell Solar & CIGSS & 3651 & $12.1^{*}$ & $44.3^{*}$ & $03 / 99$ \\
Energy PV & CIGS & 3158 & $6.2^{*}$ & $19.7^{*}$ & $04 / 97$ \\
& & & & \\
\hline
\end{tabular}

The highest power output for any thin-film monolithic module is $92.5 \mathrm{~W}$ with an aperture-area efficiency of $11.0 \%$ for an Apollo thin-film CdTe module made by BPS using the electrodeposition technique [12]. FS has fabricated a $10.1 \%$ efficient thin-film CdTe power module using the vapor transport deposition method [13]. The highest efficiency of any thin-film module is a $12.1 \%$ efficient CIGSS module fabricated by SSI using the two stage process of depositing the precursors - $\mathrm{Cu}, \mathrm{In}, \mathrm{Ga}$ by sputtering (Fig. 6) followed by the selenization process [14]. The highest efficiency for a flexible, lightweight, thin-film CIGS module is $7.4 \%$ with a power output of $57.3 \mathrm{~W}$ made by GSE uses the PVD technique [15] for absorber formation; it is shown in Fig. 7. The manufacturing cost of thin-film module fabrication is reported elsewhere [16].

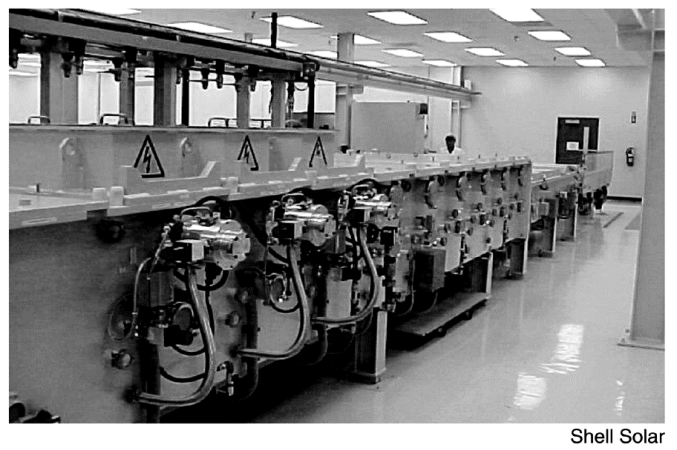

Fig. 6. Thin-Film CIGSS precursor deposition of $\mathrm{Cu}$, In, Ga by sputtering.

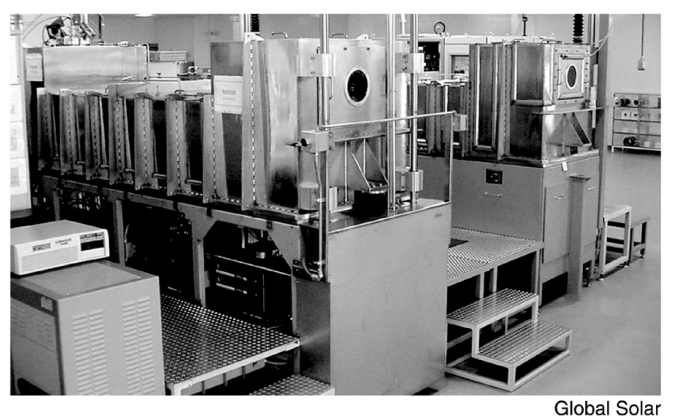

Fig. 7. Lightweight, flexible thin-film CIGS deposition by PVD.

A number of lessons have been learned in the past several years during the technology development phase of thin-film module fabrication. Table 5 summarizes several of these in terms of glass handling, equipment architecture and design, high-speed manufacturing and control of stoichiometry, thickness, and uniformity, mechanical failures due to improper design of source, delivery systems, heating elements, and malfunctioning of gauges, pumps, anode, and cathode.

Table 5. Lessons Learned

\begin{tabular}{|c|c|}
\hline $\begin{array}{l}\text { Glass (breakage, cleaning, edging, flatness, } \\
\text { handling, strength, stress, temperature, } \\
\text { thickness, warping) }\end{array}$ & $\begin{array}{l}\text { Monolithic Integration (laser versus } \\
\text { mechanical scribing, number of cells, voltage } \\
\text { design) }\end{array}$ \\
\hline \multirow{3}{*}{$\begin{array}{l}\text { - Equipment (architecture, design) } \\
\text { - High Speed Manufacturing (stoichiometry, } \\
\text { thickness, uniformity, batch versus in-line, } \\
\text { material utilization) }\end{array}$} & - Module Design (voltage, size, flexibility of \\
\hline & size, substrates) \\
\hline & - Sputter Drift (drift in rate, variation in targets) \\
\hline \multirow{2}{*}{$\begin{array}{l}\text { Mechanical Failures (source design, } \\
\text { delivery system, heating elements, gauges, } \\
\text { pumps, anode, cathode) }\end{array}$} & $\begin{array}{l}\text { - Machine Process Drift (changes in } \\
\text { deposition rates and ratios) }\end{array}$ \\
\hline & - Adhesion (back contact, semiconductor) \\
\hline $\begin{array}{l}\text { Temperature Differential (room, low, } \\
\text { medium, high) }\end{array}$ & $\begin{array}{l}\text { - Encapsulation/Packaging (corrosion, } \\
\text { delamination, edge isoloation, hermetic seal, }\end{array}$ \\
\hline \multirow{2}{*}{$\begin{array}{l}\text { Feedstocks (purity, reproducibility, } \\
\text { development) }\end{array}$} & edge sealant, intra sealant) \\
\hline & $\begin{array}{l}\text { ES\&H, Recycling, Waste Management (Cd } \\
\text { recycling, liquid, solid, maintenance, cleaning) }\end{array}$ \\
\hline
\end{tabular}


Also, we report temperature differential in going from room temperature to low and medium temperatures and finally to high-temperature regimes for depositing the absorber films. Other lessons learned are monolithic integration using laser and mechanical scribes, the sputter drift of targets, machine process drift due to residual coatings, control of external dopants, film adhesion, encapusaltio/packaging of modules to prevent corrosion and moisture ingress, and last but not least the important issue of ES\&H in a large scale manufacturing environment.

\section{APPLICATIONS}

A number of thin-film PV arrays based on CdTe and CIS modules which are either rigid or flexible are being tested worldwide. The PV systems are either stand-alone or grid-connected. The system sizes vary from 10 to 250 kW. Fig. 8 show a rooftop, grid-connected 10-kW thin-film CdTe PV array installed on the WAPA building in Folsom, CA. A 40.8-kW thin-film CIGSS PV array has been installed in Salzurg, Austria and is shown in Fig. 9. Flexible, lightweight, thin-film CIGS arrays have been deployed on tents (Fig. 10) and are used by the U.S. Army and Marines. Two solar fields using "experimental" thin-film CdTe module, whose system sizes are $175 \mathrm{~kW}$ and $250 \mathrm{~kW}$, respectively, have been deployed in Springerville, Arizona, and Dublin, California.

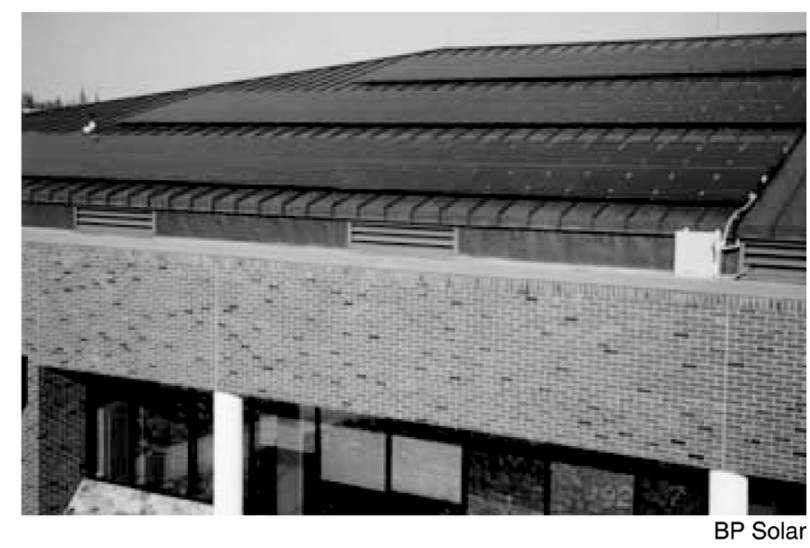

Fig. 8. 10-kW thin-film Apollo CdTe rooftop PV array.

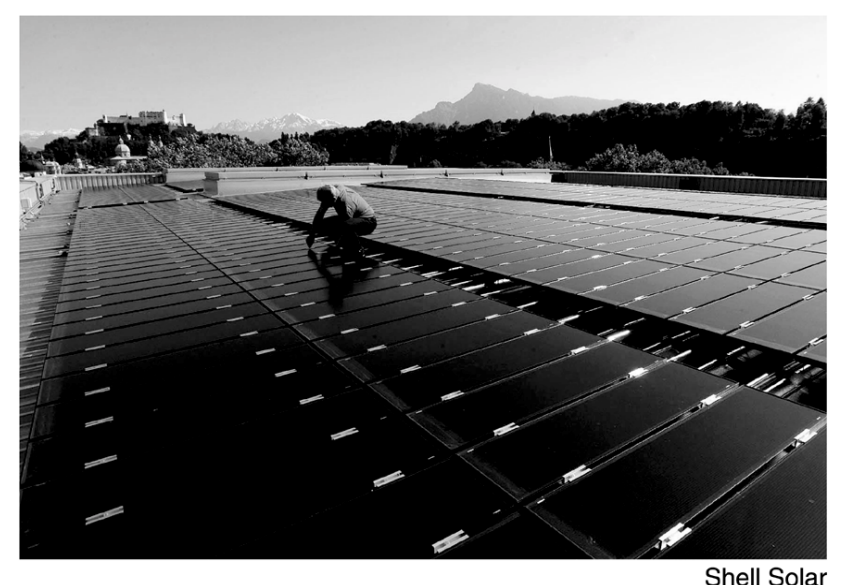

Fig. 9. 40.8-kW thin-film CIGSS PV grid-connected array at Salzburg, Austria.

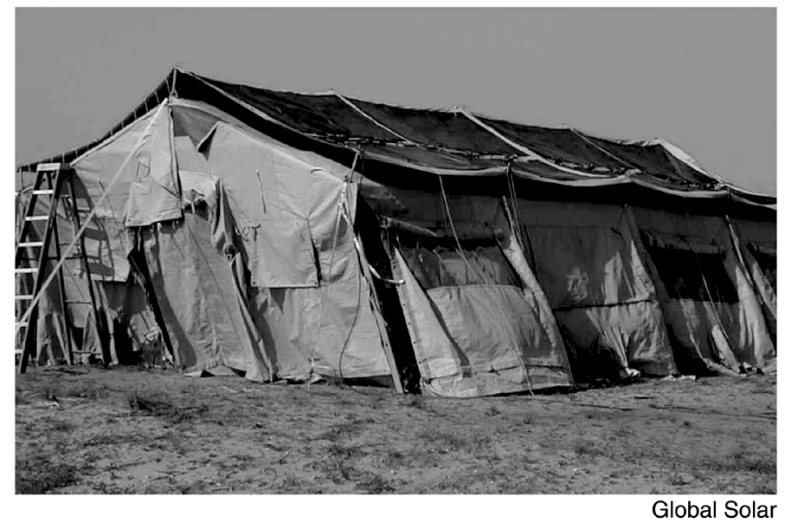

Fig. 10. Lightweight, flexible, thin-film CIGS modules deployed on U.S. Army tents.

\section{SUMMARY}

Major technical advances have occurred in the field of polycrystalline thin film compounds such as CdTe and CIS that have propelled photovoltaic research, development, and technology deployment. A world record totalarea efficiency of $16.5 \%$ has been achieved for a thin-film CdTe solar cell using a modified device structure of CTO/ZTO/CdS/CdTe/graphite by NREL scientists. Researchers at NREL have also set a world record for a thinfilm CIGS solar cell with a total-area efficiency of $21.1 \%$ under 14X concentration and AM1.5 global spectrum. When measured under AM1.5 direct spectrum, the totalarea efficiency increases to $21.5 \%$. The absorber film was grown using the three -stage process and the PVD technique. A key CdTe-related stability issue is being rigorously investigated using the ALT to understand the mechanisms and modes that causes changes in the device performance under various stress conditions. Several buffer layers to potentially replace the CBD CdS in thinfilm CIS solar cells have been highlighted. The role of moisture on thin-film CIS- based devices has been addressed. World-record power output of $92.5 \mathrm{~W}$ and aperture-area conversion efficiency of $11.0 \%$ has been achieved by BPS for a thin-film CdTe power module. For a thin-film CIS power module, SSI demonstrated an aperture-area conversion efficiency of $12.1 \%$. For flexible, lightweight, thin-film CIGS module, an aperture-area conversion efficiency of $7.4 \%$ and power output of $57.3 \mathrm{~W}$ has been fabricated by GSE. Many companies worldwide are actively involved in building manufacturing capacity for both CdTe and CIS module fabrication. Several thin-film grid-connected PV arrays in the range of 10 to $40.8 \mathrm{~kW}$ have been installed and are being tested. Two thin-film CdTe solar fields using "experimental" modules, whose system sizes are 175 and $250 \mathrm{~kW}$, respectively, are being tested in Springerville, Arizona, and Dublin, California.

\section{ACKNOWLEDGMENTS}

This work was supported by the U.S. Department of Energy under Contract No. DE-AC36-99G010337. The authors would like to thank the numerous engineers, scientists, and technicians whose data have been included in this paper. 


\section{REFERENCES}

[1] X. Wu, R. Ribelin, R.G. Dhere, D.S. Albin, T.A. Gessert, S. Asher, D.H. Levi, R. Mason, H.R. Moutinho, and P. Sheldon, "High Efficiency CTO/ZTO/CdZnS/CdS/ CdTe Polycrystalline Thin-Film Solar Cells," Proceedings of the 28th IEEE Photovoltaic Specialists Conference, Anchorage, Alaska; September 18-22, 2000 pp. 470-474.

[2] X. Nie, S.H. Wei, and S.B. Zhang, "Bipolar Doping and Band-Gap Anomalies in Delafossite Transparent Conductive Oxides," Phy. Rev. Lett. Vol. 88, No. 6, 11 February 2002, pp. 66405-1 to 66405-4.

[3] H.S. Ullal, K. Zweibel, and B.G. von Roedern, "Polycrystalline Thin-Film Photovoltaic Technologies: From the Laboratory to Commercialization," Proceedings of the 28th IEEE Photovoltaic Specialists Conference, Anchorage, Alaska, September 18-22, 2000; pp 418-423.

[4] X. Wu, J.C. Keane, R.G. Dhere, C. DeHart, D.S. Albin, A.Duda, T.A. Gessert, S. Asher, D.H. Levi,, and P. Sheldon, "16.5\%-Efficient CdS/CdTe polycrystalline ThinFilm Solar Cell," Proceedings of the 17th European Photovoltaic Solar Energy Conference, Munich, Germany; October 22-26, 2001; in press.

[5] R. Dhere, X. Wu, D. Albin, C. Perkins, H.. Moutinho, and T. Gessert, "Formation of $\mathrm{CdS}_{\mathrm{x}} \mathrm{Te}_{1-\mathrm{x}}$ alloys and Their Correlation to the Properties of CdS/CdTe Thin-Film Solar Cells," Proceedings of the 29th IEEE Photovoltaic Specialists Conference, New Orleans, LA; May 20-24; in press.

[6] X. Wu, R.G. Dhere, Y. Yan, R. Adams, C. Perkins, , H.R. Moutinho, and B. To, "High Efficiency CdTe Polycrystalline Thin Film Solar Cells with a Modified Sputtered-CdS Window Layer," Proceedings of the 29th IEEE Photovoltaic Specialists Conference, New Orleans, LA; in press.

[7] J.S. Ward, K. Ramanathan, F.S. Hasoon, T.J. Coutts, J. Keane, M.A. Contreras, T. Moriarty, and R. Noufi, "A 21.5\% Efficient Cu(In,Ga)Se2 Thin-Film Concentrator Solar Cells," Progress in Photovoltaics: Research and Applications, Vol. 10, April 2002, pp. 41-46.

[8] W. Shafarman, S. Marsillac, P.D. Paulson, M.W. Haimbodi, and R.W. Birkmire, "Optical and Device Characterization of Thin Film Cu(InAI)Se2," Proceeding of the 29th IEEE Photovoltaic Specialists Conference, New Orleans, LA, May 20-24, 2002; in press.

[9] H.S. Ullal, K. Zweibel, and B. von Roedern, "Current Status of Polycrystalline Thin-Film PV Technologies," Proceedings of the 26th IEEE Photovoltaic Specialists Conference, Anaheim, CA, September 29 - October 03, 1997; pp. 301-305.

[10] K. Ramanathan, H. Wiesner, S. Asher, D. Niles, R.N. Bhattacharya, J. Keane, M. Contreras, and R. Noufi, "High Efficiency CIGS Thin-Film Solar Cells Without Intermediate Buffer Layers," Proceedings of the 2nd World Conference on Photovoltaic Solar Energy Conference, Vienna, Austria, July 6-10, 1998; pp.477-481.

[11] J.C.C. Fan, B.Y Tsaur, and B.J. Palm, "Optimal Design of High Efficiency Tandem Cells," Proceedings of the 16th IEEE Photovoltaic Specialists Conference, San Diego, CA, September 27-30, 1982; pp. 692-701.

[12] D.W. Cunningham, M. Federick, B. Gittings, L. Grammmond, S. Harrer, J. Intagliata, N. O=Connor, M. Rubcich, D. Skinner, P. Veluchamy, "Progress in Apollo Technology," Proceedings of the 29th IEEE Photovoltaic Specialists Conference, New Orleans, LA; May 20-24, 2002; in press.

[13] D. Rose, R. Powell, U. Jayamaha, M. Maltby, A. McMaster, "Advances in Performance and High Throughput Manufacturing of Thin-Film CdS/CdTe Modules," Proceedings of the 29th IEEE Photovoltaic Specialists Conference, New Orleans, LA; May 20-24, 2002; in press.

[14] R.D. Wieting, "CIS Manufacturing at the Megawatt Scale," Proceedings of the 29th IEEE Photovoltaic Specialists Conference, New Orleans, LA, May 20-24, 2002; in press.

[15] S. Wiedeman, M. Beck, R. Butcher, I. Eisgruber, N. Gomez, B. Joshi, R.G. Wendt, and J.S. Britt, "ClGS Module Development on Flexible Substrates," Proceedings of the 29th IEEE Photovoltaic Specialists, New Orleans, LA, May 20-24, 2002; in press.

[16] K. Zweibel, "Thin Film PV Manufacturing: Materials Cost and their Optimization," Solar Energy Materials \& Solar Cells, Vol. 63, 2000; pp. 375-386. 


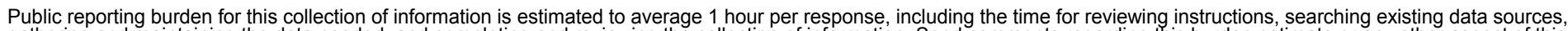

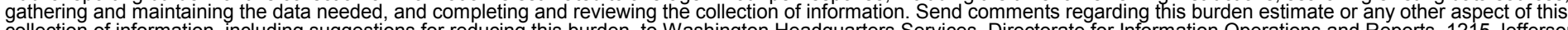

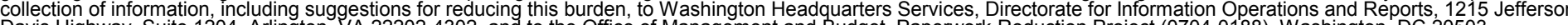
Davis Highway, Suite 1204, Arlington, VA 22202-4302, and to the Office of Management and Budget, Paperwork Reduction Project (0704-0188), Washington, DC 20503.

\begin{tabular}{|l|l|l|}
\hline 1. AGENCY USE ONLY (Leave blank) & $\begin{array}{l}\text { 2. REPORT DATE } \\
\text { May } 2002\end{array}$ & $\begin{array}{l}\text { 3. REPORT TYPE AND DATES COVERED } \\
29^{\text {th }} \\
\text { IEEE PVSC-Conference Paper } \\
\text { May 20-24 2002 }\end{array}$ \\
\hline
\end{tabular}

4. TITLE AND SUBTITLE

Polycrystalline Thin Film Photovoltaics: Research, Development, and Technologies; Preprint

6. Author(S)

H.S. Ullal, K. Zweibel, and B. von Roedern

7. PERFORMING ORGANIZATION NAME(S) AND ADDRESS(ES)

National Renewable Energy Laboratory

1617 Cole Blvd.

Golden, CO 80401-3393

9. SPONSORING/MONITORING AGENCY NAME(S) AND ADDRESS(ES)

National Renewable Energy Laboratory

1617 Cole Blvd.

Golden, CO 80401-3393
5. FUNDING NUMBERS PVP25001

8. PERFORMING ORGANIZATION REPORT NUMBER

10. SPONSORING/MONITORING AGENCY REPORT NUMBER

NREL/CP-520-32187

11. SUPPLEMENTARY NOTES

12a. DISTRIBUTION/AVAILABILITY STATEMENT National Technical Information Service

12b. DISTRIBUTION CODE

U.S. Department of Commerce

5285 Port Royal Road

Springfield, VA 22161

13. ABSTRACT (Maximum 200 words): II-VI binary thin-film solar cells based on cadmium telluride (CdTe) and I-III-VI ternary thin-film solar cells based on copper indium diselenide (CIS) and related materials have been the subject of intense research and development in the past few years. Substantial progress has been made thus far in the area of materials research, device fabrication, and technology development, and numerous applications based on CdTe and CIS have been deployed worldwide. World record efficiency of $16.5 \%$ has been achieved by NREL scientists for a thin-film CdTe solar cell using a modified device structure. Also, NREL scientists achieved world-record efficiency of $21.1 \%$ for a thin-film CIGS solar cell under a $14 \mathrm{X}$ concentration and AM1.5 global spectrum. When measured under a AM1.5 direct spectrum, the efficiency increases to $21.5 \%$. Pathways for achieving $25 \%$ efficiency for tandem polycrystalline thin-film solar cells are elucidated. R\&D issues relating to CdTe and CIS are reported in this paper, such as contact stability and accelerated life testing in $\mathrm{CdTe}$, and effects of moisture ingress in thin-film CIS devices. Substantial technology development is currently under way, with various groups reporting power module efficiencies in the range of $7.0 \%$ to $12.1 \%$ and power output of 40.0 to 92.5 W. A number of lessons learned during the scale-up activities of the technology development for fabrication of thin-film power modules are discussed. The major global players actively involved in the technology development and commercialization efforts using both rigid and flexible power modules are highlighted.

14. SUBJECT TERMS: PV; II-VI binary; thin-film solar cells; cadmium telluride (CdTe); I-III-VI ternary thin-film; copper indium diselenide (CIS); device fabrication; power modules;

15. NUMBER OF PAGES

16. PRICE CODE

17. SECURITY CLASSIFICATION OF REPORT Unclassified
18. SECURITY CLASSIFICATION OF THIS PAGE Unclassified
19. SECURITY CLASSIFICATION OF ABSTRACT Unclassified
20. LIMITATION OF ABSTRACT UL 